\title{
ANALYSING OLD TESTAMENT POETRY: BASIC ISSUES IN CONTEMPORARY EXEGESIS'
}

G T M Prinsloo

Abstract

The wealth of publications on matters relating to Old Testament poetry is witness to the fact that this subject has become a focal point in Old Testament studies. In this paper, an overview of contemporary publications is given. The basic issues, both on the level of poetic theory and practical application, are pointed out. A tendency towards a comprehensive literary approach is definitely present and should be encouraged. Only when a poem is analysed on all levels and by all means, will the richness of its meaning be appreciated.

\section{Introduction}

It can safely be stated that the analysis of poetry became one of the focal points in Old Testament studies during the past decade. The wealth of publications is a witness to this fact.

The aim of this study is neither to analyse any of these publications in detail, nor to elaborate on the history of research in this field, but simply to point out some of the basic issues in contemporary exegesis and discuss some of the problem areas yet unsolved.

\section{A constant flow of publications}

Over the past decade a constant flow of publications on the subject of the analysis of Old Testament poetry has appeared. These can be divided into two categories. Some publications elaborated on methodological issues, others on the practical analysis of the poetic corpus.

\subsection{Publications on methodological matters}

Collins' study on syntactic patterns in Hebrew poetry may be taken as point of departure in the discussion of recent publications ${ }^{2}$. According to Collins ${ }^{3}$ two basic approaches characterised studies on Old Testament poetry up to the publication of his book. On the one hand it was believed that a clear metrical principle constitutes the essence of Hebrew poetry. On the other hand the occurrence of parallelisms was regarded as the most striking phenomenon of Hebrew poetry. Collins propagated the theory that the grammatical and syntactic structure of poetic lines according to certain basic patterns constitute the essence of Hebrew poetry.

Since 1978 a vast number of publications on this subject appeared. In 1979 Geller 
discussed the nature and function of parallelism in Old Testament poetry ${ }^{5} .1980$ saw the publication of several articles of Freedman 6 . He paid special attention to the nature of Hebrew metre. In the same year O'Connor's study on the structure of Hebrew verse as well as Van der Lugt's analysis of strophic structures in the Psalms ${ }^{8}$ were published. In 1981 Kugel's book on the nature of parallelism in Hebrew poetry ${ }^{9}$ followed. In 1984 Watson's book on Biblical Hebrew poetry ${ }^{10}$ was published. Watson analysed and described virtually every aspect of Biblical poetry. The same year saw the publication of Krasovec's study of antithetic structures in Biblical Hebrew poetry ${ }^{11}$. Alter's study of Hebrew poetry followed in $1985^{12}$. He gave a comprehensive analysis of parallelism as poetic device. There are many points of contact between his book and Kugel's. The metre of Hebrew verse was the subject of Van Grol's study which appeared in $1986^{13}$. Many of the new trends in research on Hebrew poetry were touched upon in a volume of essays edited by Follis, which appeared in $1987^{14}$. In 1962 Alonso Schökel published a study on Hebrew poetry. A revised and enlarged edition appeared in $1988^{15}$. In this book, he gave a comprehensive analysis of various characteristics of Hebrew poetry. In the same year a number of essays by various Dutch scholars from the Theological School in Kampen were published, with Van der Meer and De Moor as editors ${ }^{16}$. It contained the results of research done by a research team on Hebrew poetics.

In the South African context, this flow of publications did not pass by unnoticed. In various publications Burden paid attention to the theory of Hebrew poetics ${ }^{17}$. In 1989 $\mathrm{Nel}$ discussed the problem areas in research on Hebrew poetry at length ${ }^{18}$ and made valuable remarks on shortcomings in contemporary studies. In the same year Cloete discussed the problems and nature of Hebrew rhythmics in great detail ${ }^{19}$. In my own dissertation I applied a comprehensive literary approach to Hebrew poetry on the book of Habakkuk ${ }^{20}$.

\subsection{Publications on the analysis of individual texts}

A vast number of publications in this field appeared over the past decade. Within the scope of this article, it is impossible even to give an overview of these publications. A few studies of the Psalms may be highlighted: In German publications such as the books of Strolz ${ }^{21}$, Beyerlin ${ }^{22}$, Seybold ${ }^{23}$, Zenger ${ }^{24}$, Schreiner ${ }^{25}$ and Spieckermann ${ }^{26}$ much attention has been focussed on the analysis of individual psalms. From English side Allen's commentary in the Word Biblical Commentary series ${ }^{27}$ may be mentioned. French structuralism influenced Auffret's approach to quite a large number of psalms ${ }^{28}$. The analysis of the Psalms also received much attention in South Africa. Prinsloo analysed several psalms in great detail ${ }^{29}$. Burden applied the theory of Watson to Exodus 15:1-21 $1^{30}$. Recently, a research project on poetic conventions in the Psalms has been initiated by the Department of Semitic Languages and the Department of Old Testament Studies, Faculty of Theology (Section B) at the University of Pretoria. A number of publications has appeared as a result of this research ${ }^{31}$. 


\subsection{Problem areas}

When all these publications are taken into consideration, two basic problem areas come to the surface. The first concerns the question: 'What constitutes the essence of Old Testament poetry?' The second problem is: 'How does one apply the theory of poetry to individual poems?' or, to put it another way: 'How does one go about to analyse a poem?'

\section{The problem areas in perspective}

\subsection{The essence of Hebrew poetry}

In recent publications, no agreement exists when the question is asked: What constitutes the essence, what are the main characteristics of Old Testament poetry? Different answers are given to this question.

\subsubsection{Parallelism}

The theory that the existence of poetic lines with two basically equal or parallel half-lines or feet $^{32}$, is the most outstanding characteristic of Hebrew poetry, is propagated by a large number of contemporary exegetes. However, diverging views exist as to the exact nature of parallelism ${ }^{33}$. Geller ${ }^{34}$ regards parallelism as a grammatical and semantic phenomenon. Kugel ${ }^{35}$ emphasises the semantic aspect of parallelism and points out that the second foot is not a mere repetition of the first, it has an emphatic character, it supports the first, 'carries it further, backs it up, completes it, goes beyond it' ${ }^{36}$. Alter's analysis of parallelism ${ }^{37}$ largely corresponds to the views of Kugel. Burden ${ }^{38}$ describes parallelism as a figure of speech but relates it to balance on the cognitive level as well. The exact nature of the relationship between the cognitive and literary structure is, however, not spelled out.

The importance of parallelism as characteristic of Hebrew poetry, can't be denied. On the other hand, parallelism should not be regarded as the feature which distinguishes Hebrew poetry from other poetry. Many poetic lines do not contain parallelisms ${ }^{39}$. A large amount of monostichs and tritichs occur in Hebrew poetry, often without any trace of syntactic or semantic parallelisms. Therefore Nel's warning ${ }^{40}$ that parallelism should not be regarded as the only criterium in declaring a text as poetry, must be taken to heart.

\subsubsection{Metre}

The question as to the nature of Hebrew rhythmics is very controversial. On the one hand Kugel is of the opinion that metre does not exist in Hebrew poetry. He regards parallelism as 'the only meter of biblical poetry' ${ }^{\prime 1}$. On the other hand the long standing theory that a combination of accentuated words according to certain patterns constitutes the essence of Hebrew metrics ${ }^{42}$, is defended. Watson points out that no poem has the same metric pattern throughout ${ }^{43^{\prime}}$. Therefore other models have been proposed 
which give a more constant pattern. Thus Cross ${ }^{44}$ and Freedman ${ }^{45}$ count syllables, while Loretz ${ }^{46}$ counts consonants. When everything is taken into consideration, it seems best to conclude with Watson ${ }^{47}$ that the mechanical counting of consonants or syllables does not do justice to the subtleties of Hebrew rhythmics. The theory of accentuating metric patterns still seems to be the most viable possibility ${ }^{48}$. It is confirmed by Van Grol's detailed analysis of several poetic texts ${ }^{49}$. Van Grol points out that rhythmic patterns often don't occur on the level of individual lines, but in strophes where each strophe has a strophic 'theme's0.

On the one hand, the existence of metre in Hebrew poetry should not be denied. On the other hand the value of metre should not be overestimated. Metre is not the only criterium to distinguish poetry from prose. The modern exegete simply does not have enough information about the metre of Old Testament poetry to make accurate calculations about it's characteristics. Thus metre could never play a decisive role in the analysis of a poem. Every effort to emend texts simply to get an even metrical pattern, must be rejected.

\subsubsection{Syntactic patterns}

Collins deliberately wants to deviate from the traditional approach to Old Testament poetry where either parallelism or metre played the decisive role. According to him the syntax of poetic lines is the decisive characteristic of Hebrew poetry. He claims: 'a poet's syntax is the most fundamental aspect of his effort to produce the ordered unity of words which is his poem ${ }^{\prime 51}$. Collins analyses a large amount of poetic lines and reaches the conclusion that four basic types of sentences occur in Hebrew poetry. They combine to form four general lyne-types ${ }^{52}$. According to Collins all Hebrew poetic lines can be classified according to this system.

Collins' book did bring new perspective in the debate on the essence of Hebrew poetry. His system forces the exegete to analyse the text in detail. However, Collins' theory is one-sided. The syntax of a poem is but one of the constituent parts of the whole poem. Collins based his analysis on the prophetic corpus and even there he analysed only a limited number of lines. Thus the basis for his theory is not broad enough to cover all poetic lines. The essence of Hebrew poetry should not be sought in the syntax of individual lines.

\subsubsection{A comprelensive appronch}

It is clear that no single theory can succeed in describing the essence of Hebrew poetry. Both language and the process of understanding an utterance and deriving meaning from it, are complex. In the end any given utterance becomes intelligible only after all its constituent parts are taken into consideration.

What is needed, therefore, is a comprehensive approach to poetry. In many of the recent publications exactly this is propagated.

O'Connor uses structural criteria to describe the nature of a poetic line ${ }^{53}$. In this process he combines the syntactic, metric and parallellistic approaches. According to O'Connor certain markers (tropes) provide the links between the constituent parts of a text. The 
markers occur on the morphological, syntactic and structural levels. Unfortunately $\mathrm{O}^{\prime} \mathrm{Connor}$ does not pay enough attention to some obvious markers in a text. He ignores the existence of inclusio, changes in person, repetition of certain words or the repetition of identical forms in his approach to Old Testament poetic texts. He, also, does not take all the constituent parts of a poem into consideration.

Wanke's approach represents a step in the right direction ${ }^{54}$. He indicates that a text should be analysed on different levels, namely on the phonological, morphological and syntactic levels. When dealing with poetry, metre, figures of speech and other poetic techniques should also be accounted for. In accordance with this, Hrushovsky ${ }^{55}$ regards the essence of Hebrew poetry as the intimate, almost inseparable relationship between the semantic, syntactic and accentual aspects of its rhymic patterns of language'. This definition implies that a comprehensive approach is a necessity when dealing with Old Testament poetry.

The methodology of Watson ${ }^{56}$ represents such a comprehensive approach. Watson follows the following steps in his analysis of a poem: Demarcation, segmentation, detailed analysis of individual strophes, discussion of poetic techniques, tabulation, synthesis and comparison with other literature. Van der Lugt's approach ${ }^{57}$ towards the analysis of strophes and stanzas corresponds to that of Watson. A comprehensive approach is also characteristic of Alonso Schökel's ${ }^{58}$ analysis of Hebrew poetry. He focuses attention on phonological patterns, rhythm, parallelism, synonyms, repetition, merism, antithesis, figures of speech, dialogue and monologue and development and composition. According to Korpel \& De Moor ${ }^{59}$ a step by step approach to Hebrew poetry, where the exegete works from the smallest element to the large composition, provides the most fruitful results. This is also stressed by Burden ${ }^{60}$. He concludes that all poetic conventions should be taken into account because they convey meaning in a poetic text. Nel ${ }^{61}$ warns that a poetic text should not be reduced to its syntactic and semantic levels, but that a structural-semiotic approach should be followed where each level of the text receives appropriate attention.

\subsubsection{Tendency}

When all these publications are taken into account, a tendency towards a comprehensive approach is definitely present. No single feature of Old Testament poetry is dominant enough to be described as the essence of poetry. Rather, Hebrew poetry is the sum-total of all the individual features.

\subsection{The interpretation of individual texts}

When publications on individual poems are taken into consideration, two main themes can be singled out. The first is the question whether the emphasis should lie on the final form of the text or the redactional process which lies at the back of the text. The second is the question whether the Gattung and Sitz im Leben of a text should play a decisive role in its interpretation. 


\subsubsection{Redaction history versus final composition}

In virtually every study on any poetic text, one of the main issues is the question whether a poem should be analysed as a work of art with a coherent structure or an anthology of fragments from different authors. In German theology it became customary to take the history of a text as point of departure ${ }^{62}$. In recent publications, however, this is no longer taken for granted. Zenger's ${ }^{63}$ analysis of various psalms can be taken as example. While he refers to the history of a text from time to time, the emphasis lies on the strophic structure. Seybold ${ }^{64}$ takes it as his point of departure 'dass Texte nach einem bestimmten Plan gestaltet sind, der sich bewusst oder unbewusst in ihnen realisiert'. Mittmann's studies on Psalm $23^{65}$ and Zechariah $8: 1-8^{66}$ illustrates the shift from the history of a text to the detailed analysis of the text itself very clearly. This is also true of the studies of Diedrich on Psalm $2^{67}$ and Irsigler on Psalm $22^{68}$. Auffret's structuralistic approach to the Psalms ${ }^{69}$ leaves no room for the redactional history of texts. Allen ${ }^{70}$ pays much attention to the structure of a psalm. Many publications in the South African context also breaths this spirit ${ }^{71}$.

\subsubsection{Gattung}

Ever since the time of Gunkel ${ }^{72}$ it has become customary to fit every poem into a literary category (Gattung), which in turn emanates from a specific setting of life (Sitz im Leben). The Gattungen of the Psalms are usually related to the cult. While Gunkel conceded that a Gattung does not necessarily reflect a specific Sitz im Leben ${ }^{73}$, his successors became rigid in their theory that every Gattung in the Psalms should be connected to the cult ${ }^{74}$. This approach widely influenced the exegesis of the Psalms, as can clearly be seen in the popular commentary of Kraus ${ }^{75}$.

In recent publications the strong emphasis on Gattung and Sitz im Leben makes room for emphasis on the meaning of individual texts. No one can deny that the genre of a text plays an important role in interpretation ${ }^{76}$, but it is equally true that a genre provides the recipe, the general outline, which individual authors may adapt to fit their own needs. All too often in the past texts were altered to correspond exactly to a theoretical Gattung - that without any textcritical motivation, or the meaning of a poem was limited to suit only a specific Sitz im Leben. Zenger's analysis of Psalm $4^{77}$ clearly represents a shift in emphasis. He indicates that Gunkel has been misunderstood by his followers. Gunkel saw the Psalms as 'geistliche Lieder' which came from the 'religiösen Leben des einzelnen Frommen'. A detailed analysis of the text should precede any reference to Gattung and Sitz im Leben. Only when the poem is understood, can it be interpreted against the sociohistorical situation of Old Testament times ${ }^{78}$. In this field there is a gradual shift towards a literary approach.

The question of the literary genre of a text will always remain an important one. In recent publications the tendency is to make the question of genre dependent upon the interpretation of the individual text as a literary work of art and not vice versa. 


\subsubsection{Tendency}

It is impossible to pay attention to the hundreds of publications on individual psalms. It is by no means a simple task to apply the theory of poetic texts in practice. There are as many applications as there are authors. However, a shift towards emphasis on the literary qualities of individual poems seems to become increasingly popular.

\section{Conclusion}

The analysis of Old Testament poetry is controversial. No single theory has yet established itself as the ultimate method. The flow of publications is indicative of an intense struggle to come to grips with the many facets of poetry. Exegetes seem to realise that no one-sided theory can do justice to the richness of Old Testament poetry. Thus the movement towards a comprehensive approach is promising. Only when a poem is analysed on all levels and by all means at the exegete's disposal, can it be appreciated for what it is really worth. In the context of this paper, it has been impossible to propose a specific comprehensive approach - that I hope to accomplish in another publication.

NOTES

1 During July and August 1990 I had the privilege to visit several colleagues in Europe and discuss this subject in depth. I visited the following colleagues: R E Clements (London), $M$ Vervenne (Leuven). Th Booij (Amsterdam), K Koch (Hamburg), E Zenger (Münster), S Mittmann (Tübingen), J Jeremias (Munich) and $K$ Seybold (Basel). Many of the ideas expressed in this article are the result of my discussions with these scholars. I sincerely hope this article will be a tribute to their hospitality and scholarly insight.

2 T Collins, Line-forms in Hebrew poetry: A grammatical approach to the stylistic study of the Hebrew prophets, (Studia Pohl Series Maior 7), Rome 1978.

3 Collins, op. cit., 5-6.

$4 \quad$ Collins, op.cit., 7.

5 S A Geller, Parallelism in early Biblical poetry, (HSM 20), Missoula 1979.

6 D N Freedman, Pottery, poetry, and prophecy: Studies in early Hebrew poetry, Winona Lake 1980.

7 MO'Connor, Hebrew verse structure, Winona Lake 1980.

B P van der Lugt, Strofische strukturen in de Bijbels- Hebreeuwse poēzie: De geschiedenis van het onderzoek en een bijdrage tot de theorievorming omtrent de strofenbou van de Psalmen, (Dissertationes Neerlandicae Series Theologica), Kampen 1980.

9 J L Kugel, The idea of Biblical poetry: Parallelism and its history. New Haven 1981. 
10 W G E Watson, Classical Hebrew poetry. A guide to its techniques, (JSOT Supplement Series 26), Sheftield 1984.

$11 \mathrm{~J}$ Krasovec, Antithetic structure in Biblical Hebrew poetry, (Vetus Testamentum Supplements 35), Leiden 1984.

12 R Alter, The art of biblical poetry, New York 1985.

13 HW M van Grol, De versbouw in het klassieke Hebreeuws: Fundamentele verkenningen, Amsterdam 1986.

14 E R Follis (ed), Directions in Biblical Hebrew poetry, (JSOT Supplement Series 40), Sheffield 1987.

15 L Alonso Schökel, A manual of Hebrew poetics (translated by A Graffy), Roma 1988.

16 W van der Meer \& J C de Moor (eds). The structural analysis of Biblical and Canaanite poetry, (JSOT Supplement Series 74), Sheffield 1988.

17 Cf the following publications by J J Burden: "Poetic Texts", in F E Deist \& WS Vorster, Words from afar, (The Literature of the Old Testament 1), Cape Town 1986; "Reconsidering parallelism in the Old Testament", OTE vol 4 (1986), 141-176; "Poëtiese konvensies in die Ou Testament: draers van betekenis?", in W S Prinsloo \& W Vosloo (red), In mensetaal oor God se woord. Huldigingsbundel opgedra aan professor $A H$ van Zyl. Kaapstad 1988, 10-22.

18 P J Nel, "Ou-Testamentiese poësie. Metodologie en perspektief", Acta Academica vol 21 (1989), 61-77.

19 W T W Cloete, "The concept of metre in the Old Testament", Journal for Semitics vol 1 (1989), 39-53.

20 G T M Prinsloo, 'n Literêr-eksegetiese analise van die boek Habakuk. Pretoria 1989.

21 W Strolz (hrsg), Aus den Psalmen leben. Das gemeinsame Gebet vor Kirche und Synagoge neu erschlossen,Freiburg 1979.

22 W Beyerlin, Wider die Hybris des Geistes: Studien zum 131. Psalm, (Stultgarter Bibelstudien 108), Stuttgart 1982.

23 K Seybold, Die Psalmen: Eine Einführung, (Urban-Taschenbücher 382), Stuttgart 1986.

24 E Zenger, Mit meinem Gott überspringe ich Mavern: Einführung in das Psalmenbuch, Freiburg 1987.

25 J Schreiner (hrsg), Beiträge zur Psalmenforschung. Psalm 2 und 22,(Forschung zur Bibel), Würzburg 1988.

26 H Spieckermann, Heilsgegenwart. Eine Theologie der Psalmen, Göttingen 1989.

27 L C Allen, Psalms 101-150,(Word Biblical Commentary), Waco 1983. 
28 Cf P Auffret, La sagesse a bati sa maison. Etudes de structures littéraires dans l'Ancien Testament et spécialement dans les Psaumes, Göttingen 1982, to name but one of his many publications.

29 Cf W S Prinsloo, Van kateder tot kansel: 'n Eksegetiese verkenning van enkele Psalms, Pretoria 1984 and Die Ou Testament, 'n Verouderde boek? Enkele gedagtes na aanleiding van Psalm 15, Pretoria 1987.

$30 \mathrm{~J} \mathrm{~J}$ Burden, "A stylistic analysis of Exodus 15:1-21: Theory and practice", in Exodus 1-15: Text and context, Edited by J J Burden, (OTWSA 29), Pretoria 1987.

31 CfWS Prinsloo, "Psalm 3: Die Here alleen bewerk verlossing", $N G T$ vol 30 (1989), 392-402; J H Potgieter, "Psalm 26 - "Lees maar, er staat niet wat er staat", in Prinsloo \& Vosloo, op. cit., 105-116, J H Potgieter, Semitiese Tale: Verlede, hede en toekoms aan die Universiteit van Pretoria, Pretoria 1989 (an analysis of Psalm 23) andJ H Potgieter, "Die lied van Hanna: 'n Digterlike bousteen", Skrif en Kerk vol 11 (1990), 66-73;G T M Prinsloo, "Two poems in a sea of prose: The contents and context of Daniel 2:20-23 and 6:27-28", Paper read at the third annual meeting of the South African Society for Semitics, 4-6 June 1990.

32 The research unit at the University of Pretoria avoids the traditional terms 'stich' and 'hemistich' when referring to a line of poetry. The term 'hemistich' implies that a line of poetry consists of two parts, which is not true of many lines of Old Testament poetry. Therefore the constituent parts of a poetic line are called 'feet'.

$33 \mathrm{Cf}$ the discussion in $\mathrm{Nel}$, op. cit., 63-69.

34 Geller, op. cit.

35 Kugel, op. cit.

36 Kugel, op. cit., 52.

37 Alter, op. cit.

38 Burden, Reconsidering parallelism, 141-176

39 Cf Collins, op. cit., 9.

$40 \quad$ Nel, op. cit., 69.

41 Kugel, op. cit., 301.

42 Cf B Hrushovsky, "Prosody, Hebrew", in Encyclopaedia Judaica vol 13, Jerusalem 1971.

43 Watson, op. cit., 98.

44 F M Cross, "Studies in the structure of Hebrew verse: The prosody of the psalm of Jonah" in The quest for the kingdom of God: Studies in honour of George E Mendenhall, Edited by H B Huffmann, F A Spina \& A R W Green, Winona Lake 1983.

45 D N Freedman, Pottery, poetry, and prophecy: Studies in early Hebrew poetry, Winona Lake 1980. 
46 O Loretz, "Eine kolometrische Analyse von Psalm 2", in Beiträge zur Psalmenforschung. Psalm 2 und 22, (Forschung zur Bibel), Herausgegeben von J Schreiner, Würzburg 1988, 7. 26

47 Watson, op. cit., 103-110.

$48 \mathrm{Cf}$ the discussion in Cloete, op. cit., 39-53.

49 Van Grol, op. cit., 1986 and also his article: "Classical Hebrew metrics", in W van der Meer \& J C de Moor, op. cit., 1988, 186-206.

50 Cl Van Grol, op. cit., 1988, 202.

51 Collins, op. cit., 11.

52 Cf Collins, op. cit., 23-24. The four basic types of sentences are: $N P 1+V, N P 1+V+M$, $N P 1+V+N P 2$ and NP1 $+V+N P 2 V+M$. They combine in different ways to form four general line-types: A line consisting of only one basic sentence, a line consisting of two basic sentences of the same kind with all the constituents of the firsthalf-line present in the second, a line consisting of two basic sentences of the same kind with only some of the constituents of the first half-line present in the second and a line consisting of two different basic sentences.

53 O'Connor, op. cit., 54-166

54 G Wanke, "Sprachliche Analyse", in Exegese de Alten Testaments: Einführung in die Methodik, (Uni-Taschenbücher 267), Herausgeben von G Fohrer, H W Holfmann, F Huber, L Markert \& G Wanke, Heidelberg $1979,57-81$.

55 Hrushovsky, op. cit., 1200.

56 Watson, op. cit., 11-65.

57 Van der Lugt, op. cit., 210-224.

58 Alonso Schökel, op. cit.

59 M CA Korpel \& J C de Moor. "Fundamentals of Ugaritic and Hebrew poetry" in Van der Meer \& De Moor, op. cit., 1-61.

60 Burden, Poetic texts, 1986, 39-71 and op. cit., 1988, 10-22.

61 Nel, op. cit., 70-71.

62 Cr Spieckermann, op. cit., who emphasises the fact that each psalm grew over a long period of time.

63 Zenger, op. cit.

64 Seybold, op. cit., 65.

65 S Mittmann, "Aufbau und Einheit des Danklieds Psalm 23", $2 T K$ vol 77 (1980), 1-23. 
S Mittmann, "Die Einheit von Sacharja 8,1-8", in Text and context. Old Testament and Semitic studies for F.C. Fensham, Edited by W Claassen, (JSOT Supplement Series 48), Sheffield 1988, 269-282.

67 F Diedrich, "Psalm 2 - überlegungen zur Endgestalt des Psalms", in Schreiner, op. cit., 27-71.

$68 \mathrm{H}$ Irsigler, "Psalm 22: Endgestalt, Bedeutung und Funktion", in Schreiner, op. cit., 193-239.

69 Auffrett, op. cit.

70 Allen, op. cit.

71 Cf. WS Prinsloo, op. cit., 1984 and op. cit., 1987; Burden, op. cit., 1987; Potgieter, op. cit., 1988, 1989 and 1990; GTM Prinsloo, op. cit., 1990.

72 H Gunkel, Einleitung in die Psalmen: Die Gattungen der Religiösen Lyrik Israels, Göttingen 1933.

73 Gunkel, op. cit., 181.

74 Cf S Mowinckel, Psalmstudien I, Awän und die individuellen Klagepsalmen1, Amsterdam 1921, 134-157 and Psalmenstudien III. Kultprophetie und prophetischen Psalmen. Amsterdam 1923, 15-16; A Weiser, The Psalms: A commentary, (OTL), London 1962.

75 Cf H.J Kraus, Psalmen 1, (BKAT XV/I), Neukirchen-Vluyn ${ }^{3} 1966$.

76 Cf J Barton, Reading the Old Testament: Method in biblical study, London 1984, 16.

77 E Zenger, “'Gib mir Antwort, Gott meiner Gerechtigkeit” (Ps 4,2): Zur Theologie des 4. Psalms" in Die alttestamentliche Botschaft als Wegweisung. Festschrift für Heinz Reinelt, Herausgegeben von J Zmijewsky, Stuttgart 1990, 377-403.

$78 \mathrm{Cf}$ the remarks in this regard by Alonso Schökel, op. cit., 10 and Nel, op. cit., 71. 